Abstracta Iranica Abstracta Iranica

Revue bibliographique pour le domaine irano-aryen

Volume 31 | 2011

Comptes rendus des publications de 2008

\title{
Maktab-e Negārgarī-e Herāt. Tehrān, Farhangestān-e Honar, 1387/2008, 465 p. [L'école de peinture de Hérat]
}

\section{Ghazaleh Esmaeelpour Ghoochani}

\section{(2) OpenEdition \\ Journals}

Édition électronique

URL : http://journals.openedition.org/abstractairanica/39611

DOI : 10.4000/abstractairanica.39611

ISSN : 1961-960X

Éditeur :

CNRS (UMR 7528 Mondes iraniens et indiens), Éditions de l'IFRI

\section{Édition imprimée}

Date de publication : 15 mai 2011

ISSN : 0240-8910

Référence électronique

Ghazaleh Esmaeelpour Ghoochani, « Maktab-e Negārgarīe Herāt. Tehrān, Farhangestān-e Honar 1387/2008, 465 p. [L'école de peinture de Hérat] », Abstracta Iranica [En ligne], Volume 31 | 2011, document 185, mis en ligne le 11 octobre 2012, consulté le 02 octobre 2020. URL : http:// journals.openedition.org/abstractairanica/39611; DOI : https://doi.org/10.4000/abstractairanica. 39611

Ce document a été généré automatiquement le 2 octobre 2020.

Tous droits réservés 


\title{
Maktab-e Negārgarī-e Herāt. Tehrān, Farhangestān-e Honar, 1387/2008, 465 p. [L'école de peinture de Hérat]
}

\author{
Ghazaleh Esmaeelpour Ghoochani
}

1 Ce livre de 465 pages porte sur la peinture persane sous les Timurides (1378-1507). Un sujet depuis longtemps traité, mais uniquement comme une partie des ouvrages généraux consacrés à la peinture persane, et souvent par des chercheurs européens. Cette fois, un ouvrage entier est exclusivement dédié à cette période de l'histoire de la peinture persane. Excepté l'utilisation du mot Maktab (école) qui apparaît dans le titre et qui est aujourd'hui remis en question par plusieurs spécialistes, l'A. a tenu à utiliser des données récentes, ce qui, au vu de l'état actuel de la recherche en Iran, n'était pas facile. Son travail mérite donc d'être reconnu.

2 Cette étude est divisée en trois parties, les deux premières étant consacrées aux deux périodes majeures de la peinture timuride : son apparition et sa floraison entre 1404 et 1446 ; puis son évolution et son essor de 1470 à 1505 . Plusieurs chapitres composent chacune de ces parties : ainsi le premier chapitre de la première partie revient sur le début du règne de Timour et sa politique culturelle, tandis que le second est consacré aux événements culturels, aux patrons et aux artistes de l'époque de ŠāhroH et de Bāysonqor Mīrzā. Les chapitres suivants présentent la bibliothèque royale et l'art du livre de Hérat. Plusieurs chapitres de la deuxième partie suivent le même ordre que ceux de la précédente, mais durant le règne de Solțān Ḥoseyn Bāyqarā. L'A. suppose que deux peintres ont influencé ces deux moments de la peinture timuride, c'est la raison pour laquelle il consacre la troisième et dernière partie de son ouvrage à présenter et à étudier les œuvres de ces artistes : Moḥammad Siyāh-qalam et Kamāl al-dīn Behzād. Ce livre est enrichi d'illustrations en couleur et d'une bibliographie présentant les sources principales sur le sujet. 
INDEX

Thèmes : 5.1. Monde iranophone

\section{AUTEURS}

GHAZALEH ESMAEELPOUR GHOOCHANI

Paris 